J. Lake Sci. (湖泊科学) , 2016, 28(5): 1057-1065

DOI 10. 18307/2016. 0516

(C) 2016 by Journal of Lake Sciences

\title{
丹江口水库浮游植物时空变化特征
}

\author{
王英华 ${ }^{1,2}$, 陈 雷 $^{1}$, 牛 远 $^{2}$, 余 辉 $^{2 * *}$, 罗明科 ${ }^{2}$ \\ (1: 吉林建筑大学市政与环境学院, 长春 130118) \\ (2: 中国环境科学研究院环境基准与风险评估国家重点实验室,北京 100012)
}

\begin{abstract}
摘 要: 为研究丹江口浮游植物的群落特征, 探讨影响浮游植物时空分布的环境因子, 于 2014 年 5 月- 2015 年 4 月对丹 江口水库进行了为期 1 年的调查. 此次调查共采集到浮游植物 66 种, 隶属于 7 门 21 科 38 属. 浮游植物全年平均生物量 为 $0.35 \mathrm{mg} / \mathrm{L}$, 平均密度为 $9.08 \times 10^{5} \mathrm{cells} / \mathrm{L}$. 优势种为脆杆藻、小环藻、直链藻和栅藻, 其中脆杆藻所占比例最大, 平均生 物量为 $0.089 \mathrm{mg} / \mathrm{L}$, 占总生物量的 $25.43 \%$. 近些年丹江口水库营养水平的提高可能是脆杆藻生物量升高的主要原因. 绿 藻和蓝藻在夏季大量繁殖, 硅藻为春、秋和冬季优势门类. 汉江库区浮游植物生物量大于丹江库区, 两个库区的浮游植物 种类组成存在明显的差异, 丹江库区优势门类为硅藻门, 而汉江库区为绿藻门. 浮游植物生物量与环境因子的相关分析 表明, 浮游植物生物量的主要影响因子是总磷浓度、 $\mathrm{pH}$ 值和溶解氧浓度. RDA 分析表明, 影响浮游植物组成的主要环境 因子是溶解氧浓度、 $\mathrm{pH}$ 值、总磷浓度和水温. 为控制浮游植物的生物量, 防止其异常增殖造成水华, 应严格控制外源营养 盐特别是磷元素的输人. 本研究可为丹江口水库的水质改善及富营养化防治提供一定的科学依据.
\end{abstract}

关键词: 丹江口水库;浮游植物;时空变化

\section{Spatio-temporal variation in phytoplankton community and its influencing factors in Dan- jiangkou Reservoir}

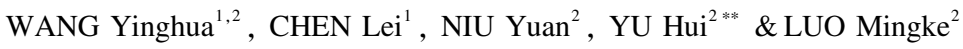 \\ (1: School of Municipal \& Environmental Engineering, Jilin Jianzhu University, Changchun 130118, P.R.China) \\ (2: State Key Laboratory of Environmental Criteria and Risk Assessment, Chinese Research Academy of Environmental Sci- \\ ences, Beijing 100012, P.R.China)
}

\begin{abstract}
In order to explore the spatiotemporal variations in phytoplankton community and its influencing factors in Danjiangkou Reservoir, we conducted a one-year survey from May 2014 to April 2015. Sixty-six species, including 38 genera, 21 families and 7 phyla, were identified in the survey. The average biomass of phytoplankton is $0.35 \mathrm{mg} / \mathrm{L}$, while the average density is $9.08 \times 10^{5}$ cells/L. Dominant species are Fragilaria spp., Cyclotella spp., Melosira spp., and Scenedesmus spp.. Fragilaria spp. is the most dominant specie, and its average biomass is $0.089 \mathrm{mg} / \mathrm{L}$, making up $25.43 \%$ of total biomass. In recent years, high level of nutrient may be the main cause of increasement in Fragilaria biomass in Danjiangkou Reservoir. Chlorophyta and cyanobacteria bloomed in summer, while diatom dominated in spring, autumn and winter. Total phytoplankton biomass in Han Reservoir is greater than that of Dan Reservoir. There were significant differences in phytoplankton composition between these two reservoirs. The dominant phylum of Dan Reservoir is Bacillariophyta, while the dominant phylum of Han Reservoir is Chlorophyta. There was significant correlation of the phytoplankton biomass with phosphorus, $\mathrm{pH}$ and dissolved oxygen, respectively. RDA analysis showed that the major environmental factors affecting phytoplankton community were dissolved oxygen, $\mathrm{pH}$, phosphorus and temperature. For preventing the algae blooms, strict measures should be taken to control the input of exogenous nutrient especially phosphorus. This study provides scientific basis for water quality improvement and control of eutrophication at Danjiangkou Reservoir.
\end{abstract}

Keywords: Danjiangkou Reservoir; phytoplankton; spatio-temporal variation

\footnotetext{
* 丹江口水库生态安全调查与评估项目资助. 2015-10-15 收稿;2015-12-23 收修改稿. 王英华 (1990 ), 女, 硕 士研究生;E-mail: 382885639@ qq.com.

** 通信作者; E-mail: yuhui@ craes.org.cn.
} 
浮游植物是水域生态系统主要的初级生产者, 同时维持食物链稳定. 浮游植物的过度繁殖或减少, 对水 域生态系统的稳定性构成极大威胁. 浮游植物群落结构、种类组成及季节变化与水质有极为密切的关系, 影 响系统内能量流和物质循环 ${ }^{[1-2]}$. 浮游植物研究者主要从温度、光照、营养盐、水动力及浮游动物摄食等方面 研究浮游植物的群落结构和分布特征 ${ }^{[3-5]}$. 浮游植物作为水质的指示生物, 在水体中尤其是湖泊、水库水体 监测中起着极为重要的作用 ${ }^{[6-7]}$.

丹江口水库位于豫、鄂、陕交界的河南省南阳市浙川县和湖北省丹江口市境内, 是国家一级水源保护 区, 是以供水、防洪、发电为主, 兼具灌溉、养殖等功能的大型水库 ${ }^{[8]}$, 属多年调节型水库, 兴建于 1958 年, 1973 年竣工. 库区呈 “V”字型, 汉江库区较细长, 丹江库区较宽阔 ${ }^{[9]}$. 水库初期蓄水位为 $157 \mathrm{~m}$, 坝顶高程为 $162 \mathrm{~m}^{[10]}$, 作为南水北调中线工程的重要水源区对大坝进行加高处理, 将蓄水位提升至 $170 \mathrm{~m}$, 库容增加至 $290.5 \times 10^{8} \mathrm{~m}^{3}$, 年调水量达 $130 \times 10^{8} \mathrm{~m}^{3}$, 有效调水量为 $95 \times 10^{8} \mathrm{~m}^{3[11]}$. 我国南水北调中线工程从丹江口水库调 水, 着重解决北京、天津、石家庄等沿线 20 多座大中城市的水资源问题, 因此水库水质状况对工程十分 重要 ${ }^{[12]}$.

近年来随着经济快速发展, 人口数量不断增加, 丹江口水库水质污染加重. 丹江口水库是南水北调中线 工程水源地, 水质影响人民健康生活以及社会经济的可持续发展. 自水库兴建开始就有很多关于浮游植物 的研究. 1958 年波鲁茨基等 ${ }^{[13]}$ 对水库进行了一次大范围的水生生物调查. 1986-1987 年杨广等 ${ }^{[14]} 、 1992-$ 1993 年邬红娟等 ${ }^{[9]} 、 2007-2008$ 年申恒伦等 ${ }^{[15]}$ 和 $2009-2010$ 年谭香等 ${ }^{[10]}$ 进行了具体的调查. 近年来在南 水北调的关键时期缺乏研究, 本调查于 2014 年 5 月 -2015 年 4 月对丹江口水库浮游植物和理化环境进行 了更详尽的研究, 旨在了解丹江口水库浮游植物群落结构以及时空变化, 对水质现状进行综合分析和生态 评价, 为保障水质安全和生态系统稳定提供科学依据.

\section{1 材料与方法}

\section{1 研究区域与样点设置}

2014 年 5 月, 根据丹江口水库 $\left(32^{\circ} 36^{\prime} \sim 33^{\circ} 48^{\prime} \mathrm{N}, 110^{\circ} 49^{\prime} \sim 110^{\circ} 59^{\prime} \mathrm{E}\right.$ ) 基本形状特征, 在丹江库区和汉江 库区分别设置 14(D1 D14) 和 10 个 (D15 D24) 采样点 (图 1), 采样点设置参见文献 [ 16].

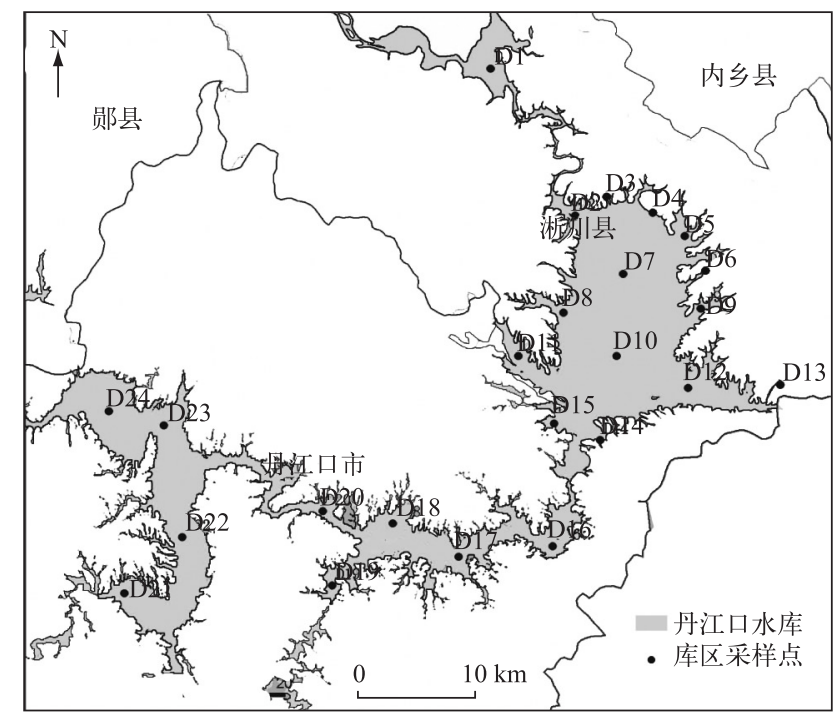

图 1 丹江口水库采样点位分布

Fig.1 Distribution of sampling sites at Danjiangkou Reservoir 


\section{2 样品采集与分析}

采集水样分为两份,其中一份用于浮游植物的定量分析,供镜检使用. 另一份带回实验室做水化学指标 分析.

供镜检使用水样为 $1 \mathrm{~L}$ 浓缩液置于塑料水样瓶中, 加人 $15 \mathrm{ml}$ 鲁哥试剂固定, 将水样沉淀 $48 \mathrm{~h}$ 后, 采用 虹吸法弃去上清液, 将水样浓缩至 $50 \mathrm{ml}$, 加人数滴福尔马林保存, 用于后期浮游植物的鉴定和定量分析 ${ }^{[17]}$. 定量分析前充分摇匀样品, 使用 $0.1 \mathrm{ml}$ 计数框 $(20 \mathrm{~mm} \times 20 \mathrm{~mm})$ 进行镜检 ${ }^{[18]}$, 在 $10 \times 40$ 倍视野下进行浮游植 物的定量计数, 每次计数 100 个视野, 每个样品统计两次, 取平均值. $1 \mathrm{~L}$ 水样中的浮游植物密度 $(N)$ 计算公 式为 ${ }^{[19]}$ :

$$
N=\left(C_{\mathrm{s}} \cdot V\right) /\left(F_{\mathrm{s}} \cdot F_{\mathrm{n}} \cdot U\right) \cdot P \mathrm{n}
$$

式中, $C \mathrm{~s}$ 为计数框的面积 $\left(\mathrm{mm}^{2}\right), F \mathrm{~s}$ 为显微镜的视野面积 $\left(\mathrm{mm}^{2}\right), F \mathrm{n}$ 为计数的视野数, $V$ 为 $1 \mathrm{~L}$ 水样浓缩后 的体积 $(\mathrm{ml}), U$ 为计数框的体积 $(\mathrm{ml}), P \mathrm{n}$ 为计数出的浮游植物个数.

选择 10 30 个浮游植物个体测定体积平均值, 用体积估算法计算浮游植物生物量 $(B)$, 公式为 ${ }^{[20]}$ :

$$
B=N \cdot V / 10^{9}
$$

式中, $N$ 为浮游植物密度, $V$ 为浮游植物体积. 浮游植物的鉴定参照《中国淡水藻类——系统、分类及生 态》 ${ }^{[21]}$.

\section{3 理化参数分析}

采用加拿大 $\mathrm{RBR}$ 公司的 XRX-620 快速多参数水质剖面仪测定水温 (WT)、 $\mathrm{pH}$ 值、溶解氧 ( DO ) 等连续 数据. 水体化学指标总磷 $(\mathrm{TP})$ 、总氮 $(\mathrm{TN})$ 、可溶性总磷 $(\mathrm{TDP})$ 、可溶性总氮 $(\mathrm{TDN})$ 、高锰酸盐指数 $\left(\mathrm{COD}_{\mathrm{Mn}}\right)$ 浓度等测定参照《湖泊富营养化调查规范》 ${ }^{[22]}$. 用塞氏盘法现场测定透明度 $(\mathrm{SD})$.

\section{4 统计分析}

利用 SPSS 软件中的 Pearson 相关分析研究浮游植物生物量与环境因子之间的关系, 并建立相关性矩阵. 运用 RDA(CANOCO 4.5, Microcomputer Power, Ithaca, NY, USA) 分析浮游植物与环境因子之间的关系, 所 选种类的平均生物量占到总生物量的 $5 \%$ 以上. 去趋势对应分析 (DCA) 可以揭示影响浮游植物群落结构的 潜在环境变量,在 lengths of gradient 中梯度最大值小于 3 即可选择线性模型进行 RDA 分析.

\section{2 结果与讨论}

\section{1 浮游植物种类组成及优势种}

此次调查共采集到浮游植物 66 种, 隶属于 7 门 21 科 38 属. 其中绿藻门 13 属 26 种, 硅藻门 9 属 21 种, 蓝藻门 8 属 9 种, 甲藻门 3 属 3 种, 隐藻门 2 属 4 种, 裸藻门 2 属 2 种, 金藻门 1 属 1 种. 硅藻门生物量占所 有门类总生物量的 $62.85 \%$, 绿藻门生物量占总生物量的 $21.55 \%$, 蓝藻门生物量占总生物量的 $7.99 \% .1958$ 年丹江口水库中硅藻门生物量占总生物量的 $92.30 \%$, 是硅藻型水库 ${ }^{[13]}$. 此次调查中硅藻门和绿藻门生物量 共占总生物量的 $84.40 \%$, 其中绿藻门生物量从 2009 年占总生物量的 $9.59 \%{ }^{[23]}$ 增加至 $21.55 \%$, 已转变为“硅 藻一绿藻” 型水库. 调查结果表明, 丹江口水库的浮游植物平均生物量为 $0.35 \mathrm{mg} / \mathrm{L}$, 平均密度为 $9.08 \times 10^{5}$ cells $/ \mathrm{L}$, 各门浮游植物的生物量和密度见表 1.

丹江口水库的优势种分别是硅藻门的具星 小环藻 (Cyclotella stelligera) 、中型脆杆藻 (Fragilaria intermedia) 和颗粒直链藻 (Melosira granulate), 绿藻门的双对栅藻 (Scenedesmaceae bijuga) 和单生卵囊藻 (Oocystaceae solitaria), 其中中型脆 杆藻所占比例最大, 平均生物量为 $0.089 \mathrm{mg} / \mathrm{L}$, 占总生物量的 $25.43 \%$. 具星小环藻平均生物量 为 $0.066 \mathrm{mg} / \mathrm{L}$, 是除脆杆藻外的主要优势种. 与 以往年份相同月份对比, 本次调查结果显示脆杆 藻的生物量与邬红娟等 ${ }^{\left[{ }^{9}\right]}$ 对丹江口水库的调查

表 1 丹江口水库浮游植物生物量和密度

Tab.1 Phytoplankton biomass and density in Danjiangkou Reservoir

\begin{tabular}{ccc}
\hline 门类 & 平均生物量 $/(\mathrm{mg} / \mathrm{L})$ & 平均密度 $/\left(\times 10^{5} \mathrm{cells} / \mathrm{L}\right)$ \\
\hline 绿藻 & 0.076 & 3.50 \\
硅藻 & 0.221 & 3.22 \\
蓝藻 & 0.028 & 1.86 \\
甲藻 & 0.017 & 0.06 \\
隐藻 & 0.005 & 0.03 \\
金藻 & 0.005 & 0.01 \\
裸藻 & 0.0002 & 0.005 \\
\hline
\end{tabular}


结果相比增长了 2 倍, 1958 年 TP 浓度从 $0.013 \mathrm{mg} / \mathrm{L}^{[15]}$ 增加至本次调查的 $0.039 \mathrm{mg} / \mathrm{L}$ (表 2), 而脆杆藻更适 宜在中营养水质中生存的生理特性 ${ }^{[24]}$ 表明, 近年来丹江口水库营养水平是脆杆藻生物量增加的主要原因. 另外硅酸盐浓度与硅藻的生长密切相关, 不过此次调查缺乏这方面的数据, 拟在今后的研究中完善.

表 2 丹江口水库理化指标统计(平均值标准差)

Tab.2 Average and standard error of physical and chemical parameters at Danjiangkou Reservoir

\begin{tabular}{lrrr}
\hline 理化因子 & 丹江库区 & 汉江库区 & 总库 \\
\hline $\mathrm{COD}_{\mathrm{Mn}} /(\mathrm{mg} / \mathrm{L})$ & $2.018 \pm 0.294$ & $1.886 \pm 0.440$ & $1.963 \pm 0.254$ \\
$\mathrm{WT} /{ }^{\circ} \mathrm{C}$ & $17.315 \pm 8.697$ & $17.595 \pm 8.444$ & $17.432 \pm 8.630$ \\
$\mathrm{SD} / \mathrm{m}$ & $2.913 \pm 0.565$ & $3.518 \pm 0.707$ & $3.165 \pm 0.369$ \\
$\mathrm{pH}$ 值 & $8.020 \pm 0.610$ & $8.225 \pm 0.655$ & $8.105 \pm 0.735$ \\
$\mathrm{DO} /(\mathrm{mg} / \mathrm{L})$ & $9.800 \pm 3.600$ & $10.600 \pm 3.700$ & $10.133 \pm 4.050$ \\
$\mathrm{TP} /(\mathrm{mg} / \mathrm{L})$ & $0.037 \pm 0.009$ & $0.042 \pm 0.008$ & $0.039 \pm 0.008$ \\
$\mathrm{TDP} /(\mathrm{mg} / \mathrm{L})$ & $0.016 \pm 0.005$ & $0.018 \pm 0.007$ & $0.017 \pm 0.007$ \\
$\mathrm{TN} /(\mathrm{mg} / \mathrm{L})$ & $1.290 \pm 0.430$ & $1.640 \pm 0.240$ & $1.436 \pm 0.510$ \\
$\mathrm{TDN} /(\mathrm{mg} / \mathrm{L})$ & $0.610 \pm 0.103$ & $0.747 \pm 0.097$ & $0.667 \pm 0.110$ \\
\hline
\end{tabular}

\section{2 浮游植物群落的季节变化}

春季, 丹江口水库浮游植物平均生物量最大, 达 $0.508 \mathrm{mg} / \mathrm{L}$, 而冬季的生物量为全年最低, 平均生物量 仅为 $0.112 \mathrm{mg} / \mathrm{L}$ (图 2).

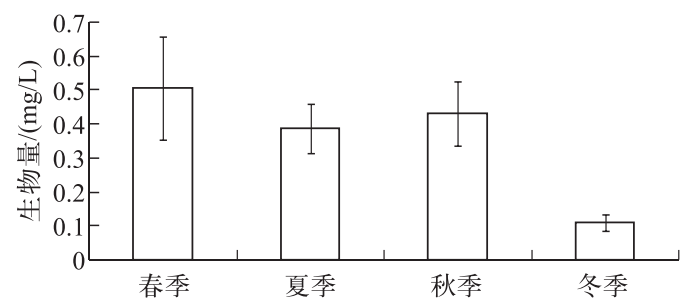

图 2 丹江口水库浮游植物生物量的季节变化

Fig.2 Seasonal variation of phytoplankton biomass in Danjiangkou Reservoir

丹江口水库浮游植物不仅总体生物量随季节有变化, 各门的生物量也随季节产生差异. 本次调查结果 表明,春、秋和冬季硅藻门生物量最大, 明显高于其他门类,夏季蓝藻和绿藻为优势门类 (图 3). 申恒伦等 ${ }^{[15]}$ 在 2007-2008 年对丹江口水库浮游植物的调查结果显示春季浮游植物以硅藻和蓝藻型为主, 夏、秋季演替 成隐藻一蓝藻型, 冬季发展为硅藻一隐藻一甲藻型, 春季和秋季硅藻所占比例最大. 谭香等 ${ }^{[10]}$ 在 $2009-$ 2010 年对丹江口水库浮游植物展开深人调查, 指出春、秋和冬季硅藻在数量上占绝对优势, 夏季蓝藻为优势 门类. 此次调查与以往研究结果大致相同, 春季和冬季均为硅藻占优势. 因为硅藻比较适合在低温的环境下 生长繁殖. 与以往研究结果不同在于, 本次研究夏季绿藻占优势, 生物量超过硅藻和蓝藻. 夏季水温最高、光 照最强, 绿藻具有竞争优势, 生物量达到峰值. 浮游植物是通过叶绿素生产力 ${ }^{[25-27]}$ 和细胞分裂速度的改 变 ${ }^{[28]}$ 来适应温度的变化, 温度改变的范围有利于浮游植物生长, 细胞分裂速度也增加 ${ }^{[29]}$.

\section{3 浮游植物的空间分布特征}

丹江口水库汉江库区采样点 $(\mathrm{D} 15 \sim \mathrm{D} 24)$ 浮游植物平均生物量为 $0.49 \mathrm{mg} / \mathrm{L}$, 丹江库区采样点 $(\mathrm{D} 1 \sim$ D14) 浮游植物平均生物量为 $0.25 \mathrm{mg} / \mathrm{L}$, 汉江库区总生物量大于丹江库区 (图 4). 丹江库区硅藻门占比例最 大, 占丹江库区总生物量的 $73.91 \%$, 汉江库区绿藻门、蓝藻门、甲藻门和隐藻门生物量明显高于丹江库区. 申恒伦等 ${ }^{[15]}$ 在 2007-2008 年对丹江口水库浮游植物调查中指出, 硅藻、蓝藻在丹江库区占比例大, 甲藻和 隐藻在汉江库区多, 汉江库区藻类密度高于丹江库区. 谭香等 ${ }^{[10]}$ 在 2009-2010 年对丹江口水库浮游植物的 研究指出, 丹江库区硅藻门占比例大, 而在汉江库区蓝藻和隐藻种群数量较高. 此次调查与以往调查结果相 


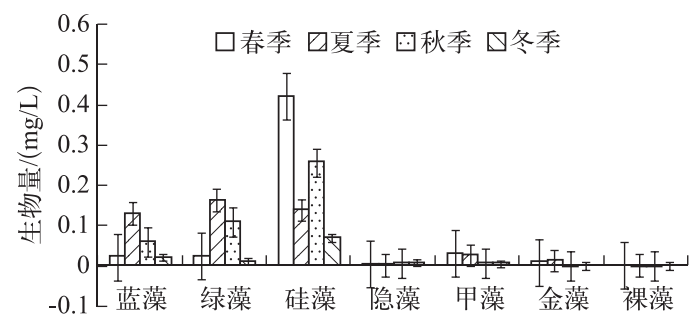

图 3 丹江口水库浮游植物各门类生物量的季节变化

Fig.3 Seasonal variations in different phyla of phytoplankton in Danjiangkou Reservoir

近,丹江库区以硅藻门为主, 汉江库区中绿藻门、蓝藻门、甲藻门和隐藻门生物量都明显高于丹江库区. 由于 丹江库区与汉江库区的容量相近, 库型和库长有很大区别, 丹江库区水域宽广, 水库岸线短, 汉江水库岸线 长且支流多, 水面长窄, 地表径流带来的外源性营养面广, 造成浮游植物多样性增加, 导致丹江库区和汉江 库区浮游植物种类和生物量的空间差异 ${ }^{[9]}$.

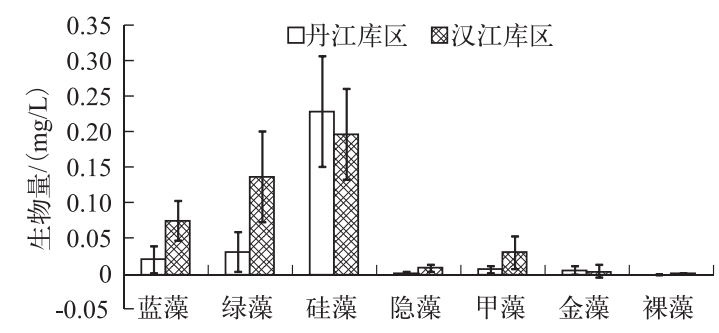

图 4 丹江口水库浮游植物各门类生物量的空间分布

Fig.4 Spatial distribution of different phyla of phytoplankton in Danjiangkou Reservoir

\section{4 浮游植物生物量与环境因子的相关性分析}

Pearson 相关分析结果表明 (表 3) , 浮游植物生物量与 DO 浓度、 $\mathrm{pH}$ 值和 TP 浓度呈极显著正相关 $(P<$ 0.01 ), 其中 TP 浓度是影响浮游植物群落的主要因素. 由于对化肥的不合理大量使用, 水体内排人大量污染 废水, 导致水体磷元素浓度升高. 因为磷肥中有可溶性的磷酸盐, 可溶性磷酸盐很大一部分被藻类利用转化 成细胞内磷, 从而水体中磷元素浓度升高, 磷元素的升高会引起浮游植物生物量的提高, 所以表现为 TP 浓 度影响藻类生物量. 在以往的研究中也指出磷元素是影响丹江口水库浮游植物生物量的主要因子, 申恒伦 等 ${ }^{[15]}$ 在 2007-2008 年对丹江口水库浮游植物展开深人调查, 结果显示磷浓度是影响丹江口水库浮游植物 密度的主要因子. 谭香等 ${ }^{[10]}$ 在 2009-2010 年对丹江口水库浮游植物的研究指出汉江库区浮游植物受磷元 素影响, 在秋季磷为整个库区的主要影响因子. 此次调查结果与以往研究结果基本一致. 淡水水体中营养 盐, 如磷是影响浮游植物演替的主要因素, 与浮游植物生长密切相关 ${ }^{[30]}$. 控制磷元素的流人, 降低水库营养 水平, 有利于丹江口水库水生生态系统健康.

$\mathrm{pH}$ 值和浮游植物生长繁殖是相互影响的, 在 $\mathrm{pH}$ 值低的水体中浮游植物生长会受到限制, 个体数量会 减少, $\mathrm{pH}$ 值高的碱性水体更有利于浮游植物进行光合作用形成有机质 ${ }^{[31]}$, 浮游植物繁殖数量增加. 如 $\mathrm{pH}$ 值在 7.5 9.0 的范围内更有利于硅藻和蓝藻的生长, 当夏季温度较高时适宜的 $\mathrm{pH}$ 值范围最利于藻类的繁 殖, 形成大规模水华 ${ }^{[32]} . \mathrm{pH}$ 值和浮游植物总生物量呈极显著正相关, 表明 $\mathrm{pH}$ 值的升高有利于浮游植物生 物量的增加, $\mathrm{pH}$ 值是影响浮游植物时空变化格局的主要因子. 浮游植物光合作用吸收水体中的二氧化碳, 改变水体 $\mathrm{pH}$ 值, 藻类自身活动也会改变水体 $\mathrm{pH}$ 值, 从而影响水体环境酸碱度 ${ }^{[33]}$. 浮游植物光合作用也会 引起水体中 $\mathrm{pH}$ 值指标的改变, 它们之间的影响是双向的.

当 DO 浓度缓慢增加时, 浮游植物密度也越来越高 ${ }^{[34]}$, 本研究也表明丹江口水库浮游植物生物量与 DO 浓度也存在着类似的关系 (表 3). 浮游植物光合作用制氧是 DO 的主要来源, 浮游植物呼吸及死亡是 DO 的 
最大消耗途径 ${ }^{[35]}$. 需要注意的是, 浮游植物的生物量与水体物理化学指标之间的影响是相互的, 浮游植物 生物量的变化也会引起水体中 DO 浓度、pH 值等指标的改变.

表 3 丹江口水库浮游植物生物量与环境指标的相关性矩阵

Tab.3 Correlation matrix of phytoplankton biomass and environmental indicators in Danjiangkou Reservoir

\begin{tabular}{|c|c|c|c|c|c|c|c|c|c|c|}
\hline & 生物量 & WT & SD & $\mathrm{pH}$ & DO & $\mathrm{TN}$ & TDN & $\mathrm{TP}$ & TDP & $\mathrm{COD}_{\mathrm{Mn}}$ \\
\hline 生物量 & 1 & & & & & & & & & \\
\hline WT & 0.337 & 1 & & & & & & & & \\
\hline SD & -0.322 & -0.157 & 1 & & & & & & & \\
\hline $\mathrm{pH}$ & $0.776^{\text {** }}$ & 0.307 & -0.192 & 1 & & & & & & \\
\hline DO & $0.574^{* *}$ & 0.503 & -0.217 & $0.805^{* *}$ & 1 & & & & & \\
\hline $\mathrm{TN}$ & -0.240 & -0.481 & $0.570^{* *}$ & -0.433 & -0.481 & 1 & & & & \\
\hline TDN & -0.443 & -0.425 & 0.185 & -0.464 & -0.319 & 0.478 & 1 & & & \\
\hline $\mathrm{TP}$ & $0.659^{* *}$ & 0.417 & 0.280 & $0.623^{\text {*** }}$ & $0.761^{* * *}$ & 0.010 & $-0.534^{* *}$ & 1 & & \\
\hline TDP & 0.485 & -0.122 & 0.215 & 0.438 & 0.356 & 0.087 & 0.013 & $0.609^{* *}$ & 1 & \\
\hline $\mathrm{COD}_{\mathrm{Mn}}$ & 0.097 & -0.039 & -0.139 & 0.298 & 0.087 & $-0.547^{* * *}$ & -0.064 & -0.068 & 0.337 & 1 \\
\hline
\end{tabular}

$*$ 表示显著性水平为 0.05 (显著), $* *$ 表示显著性水平为 0.01 (极显著).

\section{5 浮游植物优势种与环境因子的关系}

选择生物量所占比例大于 $5 \%$ 的浮游植物脆杆藻、小环藻、直链藻、栅藻和卵囊藻 (卵囊藻占 $4.87 \%$, 接 近 $5 \%$, 也纳人了分析) 与 9 个环境变量 (WT、SD、pH、DO、TN、TDN、TP、TDP 和 $\mathrm{COD}_{\mathrm{Mn}}$ ) 进行 RDA 分析. 浮游 植物与 RDA 的分析结果显示, 第 1 排序轴和第 2 排序轴特征值分别是 0.702 和 0.063 , 两轴累计变异百分率 解释了物种数据的 $76.5 \%$, 解释了物种与环境之间关系的 $98.5 \%$, 表明 5 种浮游植物与 9 个环境变量之间存 在显著相关性 (表 4). 其中最重要的因子是 $\mathrm{pH}$ 值, 解释了总变异率的 $31.65 \%$, 其次是 $\mathrm{TP}(26.20 \%) 、 \mathrm{DO}$ $(17.73 \%) 、 \operatorname{TDP}(7.52 \%) 、 \operatorname{TDN}(5.21 \%) 、 \mathrm{WT}(3.96 \%) 、 \operatorname{SD}(3.38 \%) 、 \mathrm{TN}(1.92 \%)$ 和 $\operatorname{COD}_{\mathrm{Mn}}(1.53 \%)$.

表 4 浮游植物与环境因子的相关关系

Tab.4 The correlation relationship between phytoplankton and environmental factors

\begin{tabular}{lcccc}
\hline 统计量 & 轴 1 & 轴 2 & 轴 3 & 轴 4 \\
\hline 特征值 & 0.702 & 0.063 & 0.008 & 0.004 \\
物种-环境因子相关性 & 0.875 & 0.968 & 0.984 & 0.814 \\
累计方差物种数据 & $70.2 \%$ & $76.5 \%$ & $77.3 \%$ & $77.7 \%$ \\
累计方差物种-环境关系 & $90.3 \%$ & $98.5 \%$ & $99.5 \%$ & $100 \%$ \\
\hline
\end{tabular}

$\mathrm{RDA}$ 分析显示, 脆杆藻生物量与 $\mathrm{pH}$ 值、 $\mathrm{TP}$ 浓度和 $\mathrm{DO}$ 浓度呈正相关, 与 $\mathrm{SD}$ 呈极显著负相关, 与 $\mathrm{WT}$ 、 $\mathrm{TDN}$ 浓度、TDP 浓度和 $\mathrm{COD}_{\mathrm{Mn}}$ 呈正相关; 小环藻生物量与 $\mathrm{COD}_{\mathrm{Mn}} 、 \mathrm{DO}$ 浓度、 $\mathrm{pH}$ 值和 TP 浓度呈正相关, 与 TN 浓度呈负相关, 与 $\mathrm{SD}$ 相关性不显著; 直链藻生物量与 TP 浓度呈极显著正相关, 直链藻生物量与 DO 浓度和 $\mathrm{pH}$ 值呈正相关; 桶藻生物量和卵囊藻生物量与 WT 呈显著正相关, 与 DO 浓度和 $\mathrm{pH}$ 值相关性不显著. 总体 来说, 硅藻门 (脆杆藻、小环藻、直链藻) 生物量与 DO 浓度、 $\mathrm{pH}$ 值和 TP 浓度的相关性显著, 绿藻门(椓藻、卵 囊藻)生物量与 WT 呈显著正相关(图 5).

\section{3 结论}

1) 丹江口水库浮游植物有明显的季节性变化规律, 春、秋和冬季硅藻门生物量最大, 夏季绿藻门大量生 长繁殖, 超过硅藻门. 丹江口水库的优势门类为硅藻门, 生物量占总生物量的 $62.85 \%$, 绿藻门生物量占总生 物量的 $21.55 \%$, 蓝藻门生物量占总生物量的 $7.99 \%$, 其中绿藻门的种类数在各门类中最多. 从 1958 年建坝 到 2015 年,水库浮游植物群落从硅藻型水库转变成硅藻一绿藻型水库. 


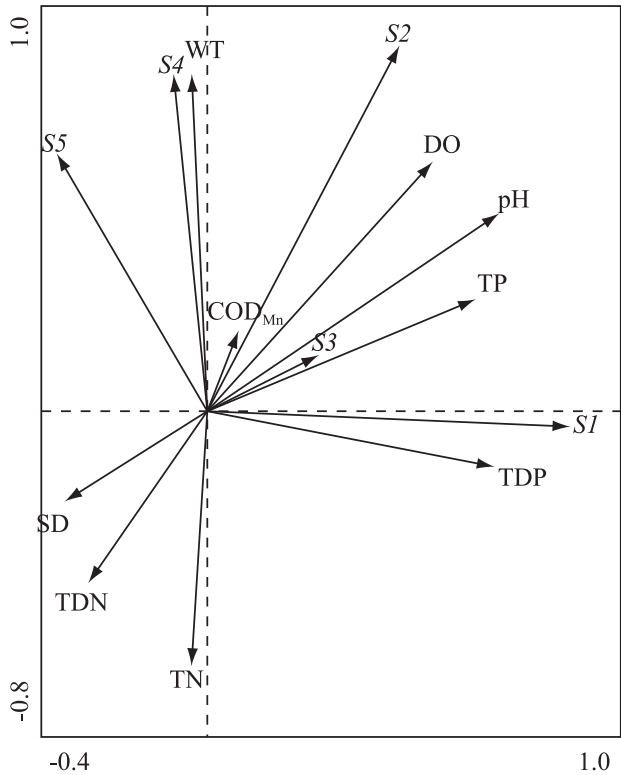

图 5 基于 RDA 分析物种与环境变量双序图

$(\mathrm{S} 1$ 为脆杆藻, $\mathrm{S} 2$ 为小环藻, $\mathrm{S} 3$ 为直链藻, $\mathrm{S} 4$ 为栅藻, $\mathrm{S} 5$ 为卵囊藻)

Fig.5 RDA double sequence diagram analysis of species and the environment variables

( S1: Fragilaria, S2: Cyclotella, S3: Melosira, S4: Scenedesmus, S5: Oocystis)

2) 丹江口水库浮游植物具有明显的空间分布特征. 丹江库区 (D1 D14) 硅藻门生物量所占比例最大 $(73.91 \%)$, 汉江库区 (D15 D24) 蓝藻、绿藻为主要类群, 硅藻门生物量所占比例比丹江库区低. 汉江库区浮 游植物总生物量大于丹江库区总生物量.

3) Pearson 相关分析结果表明, 总体来说 TP 和 DO 浓度是影响丹江口水库总生物量的主要因子, 水温也 有一定影响, 其中 $\mathrm{pH}$ 值和浮游植物生物量之间的影响是相互的. TP 浓度是影响浮游植物演替的主要因子, 与浮游植物生长密切相关. 控制磷元素流人, 降低水库营养水平, 有利于维持丹江口水库水生生态系统健康.

4) RDA 分析显示, $\mathrm{pH}$ 值和 $\mathrm{TP}$ 浓度是影响藻类生物量的主要因子. 硅藻门生物量与 DO 浓度、 $\mathrm{pH}$ 值和 $\mathrm{TP}$ 浓度相关性显著,绿藻门生物量与水温相关性显著.

\section{4 参考文献}

[ 1 ] Zhao Wen ed.Aquacultural ecology and health culuture theory of Sea Cucumber (Aportichopus juponicus Selenka) in ponds. Beijing: Science Press, 2009: 109(in Chinese). [ 赵文. 刺参池塘养殖生态学及健康养殖理论. 北京: 科学出版社, 2009: 109.]

[ 2 ] Huang Liangmin, Zhang Si, Wang Hankui et al eds. Ecological environment and biological resources in Sanya Bay. Beijing: Science Press, 2007: 105 (in Chinese).[黄良民, 张偲, 王汉奎等. 三亚湾生态环境与生物资源. 北京: 科学出 版社, 2007: 105.]

[ 3 ] Fang Tao, Li Daoji, Yu Lihua et al. Effect of irradiance and phosphate on growth of nanophytoplankton and picophytoplankton. Acta Ecologica Sinica, 2006, 26(9) : 2783-2790(in Chinese with English abstract).[方涛,李道季,余立华 等. 光照和营养盐磷对微型及微微型浮游植物生长的影响. 生态学报, 2006, 26(9) : 2783-2790.]

[ 4 ] Shen PP, Shi Q, Hua ZC et al. Analysis of microcystins in cyanobacteria blooms and surface water samples from Meiliang Bay, Taihu Lake, China. Environment International, 2003, 29(5) : 641-647.

[ 5 ] Schindler D. 1977. Evolution of phosphorus limitation in lakes. Science, 1977, 195(4275) : 260-262.

[ 6 ] Zhang X, Xie P, Chen FZ et al. Present status and changes of the phytoplankton community after invasion of Neosalanx 
taihuensis since 1982 in a deep oligotrophic plateau lake, Lake Fuxian in the subtropical China. Journal of Environmental Sciences, 2005, 17(3) : 389-394.

[ 7 ] Reynolds CS. The ecology of planktonic blue-green algae in the NorthShrop shire Meres. Field Studies, 1971, 3(2): 409-431.

[ 8 ] Straskraba M, Tundisi JG, Duncan A eds. State of the art of reservoir limnology and water quality management. Netherlands: Kulwer Academic Publisher, 1993: 213-288.

[ 9 ] Wu Hongjuan, Peng Jianhua, Han Deju. Composition and ecological chances of phytoplankton in Dan Jiang Kou Reservoir. J Lake Sci, 1996, 8(1): 43-50( in Chinese with English abstract). DOI: 10.18307/1996.0106. [鸟红娟, 彭建华, 韩 德举. 丹江口水库浮游植物及其演变. 湖泊科学, 1996, 8(1): 43-50.]

[10] Tan Xiang, Xia Xiaoling, Cheng Xiaoli et al. Temporal and spatial pattern of phytoplankton community and its biodiversity indices in the Danjiangkou Reservoir. Environmental Science, 2011, 32(10): 2875-2882 (in Chinese with English abstract). [谭香, 夏小玲, 程晓莉等. 丹江口水库浮游植物群落时空动态及其多样性指数. 环境科学, 2011, 32 (10) : 2875-2882.]

[11] He Xiaocong, Kang Ling. Runoff period analysis of Danjiangkou Reservoir: the source area of Middle Route of South-toNorth Water Transfer Project. Engineering Journal of Wuhan University, 2010, 43(1) : 30-33(in Chinese with English abstract). [ 何小聪, 康玲. 南水北调中线工程水源区丹江口水库径流周期分析. 武汉大学学报: 工学版, 2010,43 (1) : 30-33.]

[12] Fu Xinping. Situation of water resources in China and the middle route of the south to North Water Transfer Project. Water Resources \& South to North Water Diversion, 2008, (1): 1-2( in Chinese with English abstract). [ 傅新平. 我国水资源状 况与南水北调中线工程. 河南水利与南水北调, 2008, (1): 1-2.]

[13] Bo Luciji EB, Wu Xianwen, Bai Guodong et al. Hydrobiological survey of the region of the projected dam-reservoir of danjiangkou, with propositions for fisheries management. Acta Hydrobiologica Sinica, 1959, (1): 33-56 (in Chinese with English abstract). [波鲁茨基 EB, 伍献文, 白国栋等. 丹江口水库库区水生生物调查和渔业利用的意见. 水生生物 学报, 1959, (1): 33-56.]

[14] Yang Guang, Yang Ganrong, Liu Jinlan. Plankton resource survey of Danjiangkou Reservoir. Journal of Hubei Agricultural College, 1996, 8(1) : 43-50( in Chinese with English abstract). [ 杨广, 杨干荣, 刘金兰. 丹江口水库浮游生物资源调 查. 湖北农学院学报, 1996, 8(1): 43-50.]

[15] Shen Henglun, Xu Yaoyang, Wang Lan et al. Spatial and temporal variations of phytoplankton in Danjiangkou Reservoir and its affecting factors. Plank Science Journal, 2011, 29(6): 683-690(in Chinese with English abstract). [ 申恒伦, 徐 耀阳, 王岗等. 丹江口水库浮游植物时空动态及影响因素.植物科学学报, 2011, 29(6): 683-690.]

[16] Li Siyue, Cheng Xiaoli, Gu Sheng et al. Hydro-chemical characteristics in the Danjiangkou Reservoir (Water Source Area of the Middle Route of the South to North Water Transfer Project), China. Environmental Science, 2008, 29( 8): 21112116. [李思悦, 程晓莉, 顾胜等. 南水北调中线水源地丹江口水库水化学特征研究. 环境科学, 2008, 29(8): 2111-2116.]

[17] Cai Qinghua ed. Protocols for standard observation and measurement in aquatic ecosystems. Beijing: China Environmental Science Press, 2007: 29-110(in Chinese). [ 蔡庆华. 水域生态系统观测规范-中国生态系统研究网络 (CERN) 长期 观测规范丛书. 北京: 中国环境科学出版社, 2007: 29-110.]

[18] He Zhihui. Biomass of freshwater plankton: an urgent task to improve the quantitative work of plankton. Chinese Journal of Zoology, 1979, (4) : 53-56(in Chinese with English abstract). [ 何志辉. 淡水浮游生物的生物量. 动物学杂志, 1979, (4) : 53-56.]

[19] Ming Daoxu ed. Field experiment and statistical analysis( The second edition). Beijing: Science Press, 2008: 188(in Chinese). [明道绪. 田间试验与统计分析 (第二版). 北京: 科学出版社, 2008: 188.]

[20] Song Xiaolan, Liu Zhengwen, Pan Hongkai et al. Phytoplankton community structure in Meiliang Bay and Lake Wuli of Lake Taihu. J Lake Sci, 2007, 19(6) : 643-651 (in Chinese with English abstract). DOI: 10.18307/2007.0604. [ 宋晓 兰, 刘正文, 潘宏凯等. 太湖梅梁湾与五里湖浮游植物群落的比较. 湖泊科学, 2007, 19(6): 643-651.]

[21] Hu Hongjun, Wei Yinxin eds. Freshwater algae-systems, classification and ecology in China. Beijing: Science Press, 2006: 1-1023 (in Chinese). [ 胡鸿钧, 魏印心. 中国淡水藻类——系统、分类及生态. 北京: 科学出版社, 2006: $1-1023$. 
[22] Jin Xiangcan, Tu Qingying eds. Specification for investigation of lake eutrophication( second edition). Beijing: China Environmental Science Press, 1990(in Chinese).[ 金相灿, 屠清瑛. 湖泊富营养化调查规范(第二版). 北京: 中国环境 科学出版社, 1990.]

[23] Chang Qiuling, Tian Mingzhong. Comprehensive research on environment in water source region( Nan Yang City) of the middle route project for south-to-north water diversion[Dissertation]. Beijing: China University of Geosciences, 2007 (in Chinese with English abstract). [ 常秋玲. 南水北调中线水源区 (南阳市)生态环境综合研究 [学位论文]. 北京: 中国 地质大学, 2007.]

[24] Salnaso N, Morabito G, Mosello R et al. A synoptic study of phytoplankton in the deep lakes south of the Alps (lakes Garda Iseoo, Como, Lugano and Maggiore). Journal of Limnology, 2003, 62(2) : 207-227.

[25] Eppley RW. Temperature and phytoplankton growth in the sea. Fish Bull, 1972, 70(4): 1063-1085.

[26] Talling JF. The relative growth rate of three plankton diatoms in relation to underwater radiation and temperature. New Series, $19(75)$ : 329-341.

[27] Ichmura S ed. Phytoplantkon photosynthesis. In: Jackson DF ed. Algae, man and the environment. New York: Syracuse Univ Press Syracuse, 1968: 103-120.

[28] Fogg GE ed. Algal cultures and phytoplankton ecology. Madison: University of Wisconsin Press, 1965.

[29] Kuang Qijun, Ma Peiming. Study on the evaluation and treatment of lake eutrophication by means of algae biology. Journal of Safety and Environment. 2005, 4(2) : 87-91 (in Chinese with English abstract). [况琪军, 马沛明. 湖泊富营养化的 藻类生物学评价与治理研究进展. 安全与环境学报, 2005, 4(2): 87-91.]

[30] Tan Xiang, Shen Hong, Song Lirong. Annual dynamics of phytoplankton abundance and community structure in the Xionghe Reservoir. Acta Hydrobiologica Sinica, 2007, 31(5) : 693-699( in Chinese with English abstract).[谭香, 沈宏, 宋丽 荣. 熊河水库浮游植物群落结构的周年变化. 水生生物学报, 2007, 31(5) : 693-699.]

[31] Liu Xiaojiang, Shi Xinlu, Qi Guilan et al. Application of freshwater algae in monitoring water quality and sewage purification. Journal of Biology, 2010, 27(6): 76-79( in Chinese with English abstract). [ 刘晓江, 施新路, 齐桂兰等.淡水藻 类在监测水质和净化污水中的应用. 生物学杂志, 2010, 27(6): 76-79.]

[32] The ecological society panel on environmental issues ed. Environmental and biological indicator (water volume). Beijing: China Environmental Science Press, 1987 (in Chinese). [日本生态学会环境问题专门委员会. 环境和指示生物(水域 分册). 北京: 中国环境科学出版社, 1987.]

[33] Xu Hai, Liu Zhaopu, Yuan Lan et al. Effect of $\mathrm{pH}$ growth of several freshwater algae. Environmental Science \& Technolo$g y, 2009,32$ ( 1 ) :27-30 (in Chinese with English abstract). [许海, 刘兆普, 袁兰, 杨林章. pH 对几种淡水藻类生长 的影响.环境科学与技术, 2009, 32(1):27-30.]

[34] Luo Donglian. Study on the distribution of dissolved oxygen in Shenhu Bay and its relationship with phytoplankton and suspended matter. Marine Science Bulletin, 2002, 32(1) : 31-36. [罗冬莲. 深沪湾溶解氧的分布及其与浮游植物悬浮物 的相关性研究. 海洋通报, 2002, 32(1):31-36.]

[ 35] Ouyang Xiaoran, Zhao Qiaohua, Wei Yingzhu. A preliminary exploration of dissolved oxygen based on FVCOM in Meiliang Bay, Lake Taihu and its influence mechanism. J Lake Sci, 2013, 25(4) : 478-488 (in Chinese with English abstract). DOI: $10.18307 / 2013.0404$. [ 欧阳潚然, 赵巧华, 魏瀛珠. 基于 FVCOM 的太湖梅梁湾夏季水温、溶解氧模拟及其影 响机制初探. 湖泊科学, 2013, 25(4) : 478-488.] 